\title{
Development of Pervious Concrete with Different Void Contents
}

\author{
Ramesh Babu Chokkalingam
}

\begin{abstract}
Pervious or Porous concrete pavements are an alternative to rigid conventional concrete pavement surfaces. The main purpose of pervious pavements is to reduce the stagnation of rain water on the surface during rainy season by permitting the storm water percolate downwards into the ground. It is obtained by completely or partially eliminating the fine aggregates in the mixture proportions. In this work, effort has been taken to develop pervious concrete mixtures with different void contents and evaluating its mechanical properties at 28 days. From the experimental investigations performed, it was found that mix P1 with $15 \%$ void content has attained a maximum strength of 15 MPa. It was also observed from this study that the properties of pervious concrete mainly depend on the void content of the concrete mixtures.
\end{abstract}

Keywords : Pervious concrete, compressive strength, flexural strength, void content.

\section{INTRODUCTION}

The adverse effect of stagnation of water on concrete pavement surface during rainy season led to the development of pervious concrete. The main difference from the normal concrete is that fine aggregates are completely eliminated in the concrete mixture. Mostly single size aggregates are used to enrich the interconnectivity of voids, thus allowing rapid seepage of water. The void ratio of pervious concrete was typically found to be 15 to $30 \%$ depending on its application, whereas the conventional concrete is in the range of 2-4\% [1]. The strength of pervious concrete is lesser compared to normal concrete. But when there is a need for higher permeability, and a lower unit weight, pervious concrete is the only option. The density of the pervious concrete was in the ranges of 1600 to $2100 \mathrm{~kg} / \mathrm{m}^{3}$ [2]. Due to the lesser strength than conventional concrete, pervious concrete is normally laid for low traffic pavement areas such as parking areas, pathways etc. [2]. However, strength was found to be enhanced by the addition of little amount of fine aggregate in the mix proportion. It was found that adding $7 \%$ fine aggregate improved the compressive strength of pervious concrete by 57 to $84 \%$ but on the other hand the void content is reduced by 6 to $8 \%$ [3]. There is no proper procedure for mix proportioning of pervious concrete mixture. The typical void content for pervious concrete in the United States range was found to be 14 to $31 \%$ [4]. Typical mix quantities for pervious concrete have been suggested by NRMCA [5]. The addition of fine aggregate and latex has resulted in the improvement of workability and strength of pervious concrete [6]. Higher strength can be obtained by adding chemical admixtures in the pervious concrete [7].
The present work is aimed at to study the mechanical properties of pervious/porous concrete. To achieve this, mix designs have been performed with void contents ranging from $15 \%$ to $30 \%$ and studying its mechanical properties at 28 days.

\section{Experimental Program}

\section{A. Materials and Properties}

Locally available OPC 53 grade was used for the entire study. Locally available aggregates from Tirunelveli region were used and their characteristics are given in Table 1. Single size aggregate $20 \mathrm{~mm}$ was used for the entire study. Table 2 shows the particle size distribution of coarse aggregate used.

Table 1: Properties of 20mm aggregate

\begin{tabular}{|l|l|}
\hline Details & Value \\
\hline Sp. Gravity of $20 \mathrm{~mm}$ & 2.95 \\
\hline Percentage of Water Absorption & 0.5 \\
\hline Bulk Density $\left(\mathrm{kg} / \mathrm{m}^{3}\right)$ & 1550 \\
\hline Aggregate Impact Value (\%) & 22.4 \\
\hline
\end{tabular}

Table 2: Sieve analysis of $20 \mathrm{~mm}$ aggregate

\begin{tabular}{|c|c|c|c|c|}
\hline \multirow{2}{*}{$\begin{array}{l}\text { S. } \\
\text { NO }\end{array}$} & \multirow{2}{*}{ Sieve } & \multirow{2}{*}{$\begin{array}{l}\text { Wt. } \\
\text { Retained } \\
\text { G }\end{array}$} & \multicolumn{2}{|c|}{ Cumulative \% } \\
\hline & & & Retained & Passing \\
\hline 1 & $40 \mathrm{~mm}$ & 0 & 0 & 100 \\
\hline 2 & $20 \mathrm{~mm}$ & 498 & 24.90 & 75.10 \\
\hline 3 & $10 \mathrm{~mm}$ & 1487 & 99.25 & 0.75 \\
\hline 4 & $4.75 \mathrm{~mm}$ & 15 & 100 & 0 \\
\hline
\end{tabular}

\section{B. Mix Proportions, Specimen preparation and Testing} Methodology

There is no standard procedure for designing pervious concrete mixtures. Mix design has been formulated based on the void content. Cement content of the mixture was varied from 400 to $450 \mathrm{~kg} / \mathrm{m}^{3}$ in the mix design. The aggregate was proportioned based on the void content of the pervious concrete mixture. Five mix proportions were arrived by varying the void contents ranging from $15 \%$ to $30 \%$ such as $15,18,23,25$ and $30 \%$ respectively.
Published By: Blue Eyes Intelligence Engineering \& Sciences Publication 
The w/c for all the mixes was maintained at 0.35 . The final mix proportions arrived is given in Table 3. A total of 54 pervious concrete specimens were made for this study. Of these 54 specimens, 18 were cylinders $150 \mathrm{~mm}$ diameter $\times$ $300 \mathrm{~mm}$ height, and 18 were cubes $150 \times 150 \times 150 \mathrm{~mm}$ and 18 were beams $500 \times 100 \times 100 \mathrm{~mm}$. These specimens were consolidated by means of tamping rod. The tamping intensity was ensured that cement paste was not separated while tamping. When the consolidation was complete, the remaining concrete was removed by a rolling the tamping rod at the top. The mechanical properties of pervious concrete specimens were studied at the end of 28 days as per IS: 516-1959

TABLE 3: Mix Proportions of Pervious concrete

\begin{tabular}{|l|l|l|l|l|}
\hline $\begin{array}{l}\text { Mix } \\
\text { ID }\end{array}$ & $\begin{array}{l}\text { Void } \\
\text { Content } \\
(\%)\end{array}$ & $\begin{array}{l}\text { Cement } \\
\text { Content } \\
\left(\mathrm{kg} / \mathrm{m}^{3}\right)\end{array}$ & $\begin{array}{l}\text { Coarse } \\
\text { Aggregate } \\
\left(\mathrm{kg} / \mathrm{m}^{3}\right)\end{array}$ & $\begin{array}{l}\text { Water } \\
\left(1 / \mathrm{m}^{3}\right)\end{array}$ \\
\hline P1 & 15 & 450 & 1620 & 158 \\
\hline P2 & 18 & 450 & 1530 & 158 \\
\hline P3 & 20 & 430 & 1474 & 163 \\
\hline P4 & 23 & 430 & 1385 & 163 \\
\hline P5 & 25 & 410 & 1404 & 144 \\
\hline P6 & 30 & 400 & 1276 & 158 \\
\hline
\end{tabular}

\section{RESULTS AND DISCUSSION}

The density of the pervious concrete specimens prepared in the laboratory varied from 1,900 to $2,200 \mathrm{~kg} / \mathrm{m}^{3}$. It is obvious from the results that the density of the pervious concrete depends mostly on the void nature of the concrete, which has been already stated in the previous literature [11]. Figure 1 shows the density of pervious concrete mixtures with varying voids content. From the graph, it is observed that the density of around $2200 \mathrm{~kg} / \mathrm{m}^{3}$ was achieved with a void content of $15 \%$, while the density of $1900 \mathrm{~kg} / \mathrm{m}^{3}$ was achieved with a void content of $30 \%$.

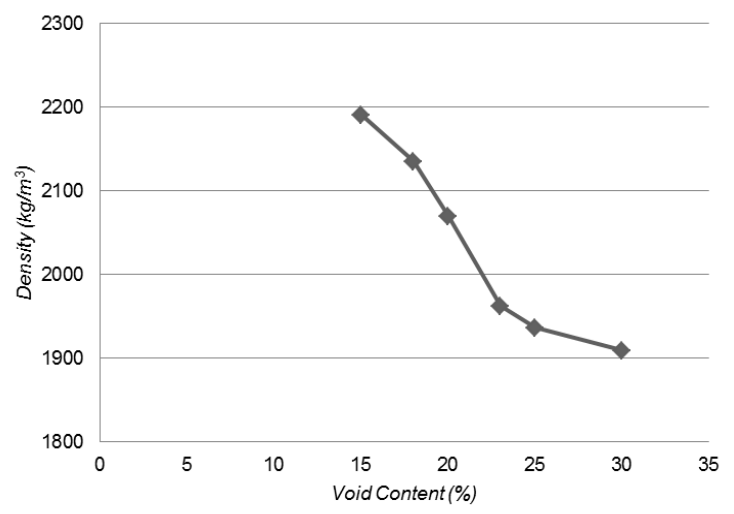

Fig. 1. Density Vs Void Content

Fig. 2. reveals the compressive strength of pervious concrete mixtures with void contents of 15, 18, 20, 23, 25 and $30 \%$ at the age of 28 days. Based on the results, it has been observed that the strength increases with the decrease in void content. The compressive strength was $15 \mathrm{MPa}$ for void content $15 \%$, while $10 \mathrm{MPa}$ for void content $30 \%$. The reduction in strength is due to increase in the void contents similar to the conventional concrete. The reduction in strength with increasing void content has been observed by various researchers [12].

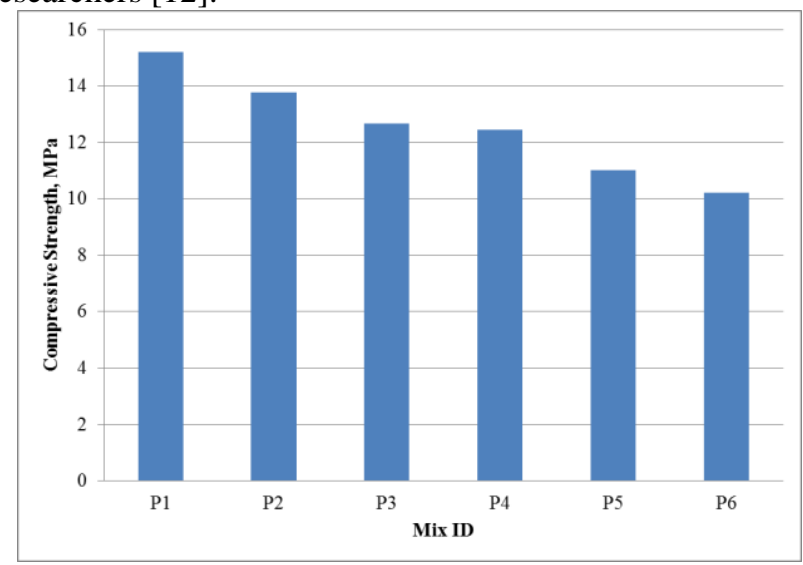

Fig. 2. Compressive Strength of Pervious Concrete Split-tensile and flexural strength test results also follow the same pattern as that of compressive strength results. The split-tensile and flexural strength results of all the six mixtures were shown in Figs. 3 and 4 respectively. The spilt tensile strength of about $0.8 \mathrm{MPa}$ was achieved at a void content of $15 \%$ and a split tensile strength of around $0.5 \mathrm{MPa}$ was achieved at a void content of $30 \%$. This clearly showed that the split tensile strength is reduced with respect to the increase in the void content. The flexural strength at the end of 28 days was $3.15 \mathrm{MPa}$ for a void content of $15 \%$, while 1.8 MPa for a void content of $15 \%$. The flexural strength also follows the same pattern as that of the split-tensile strength.

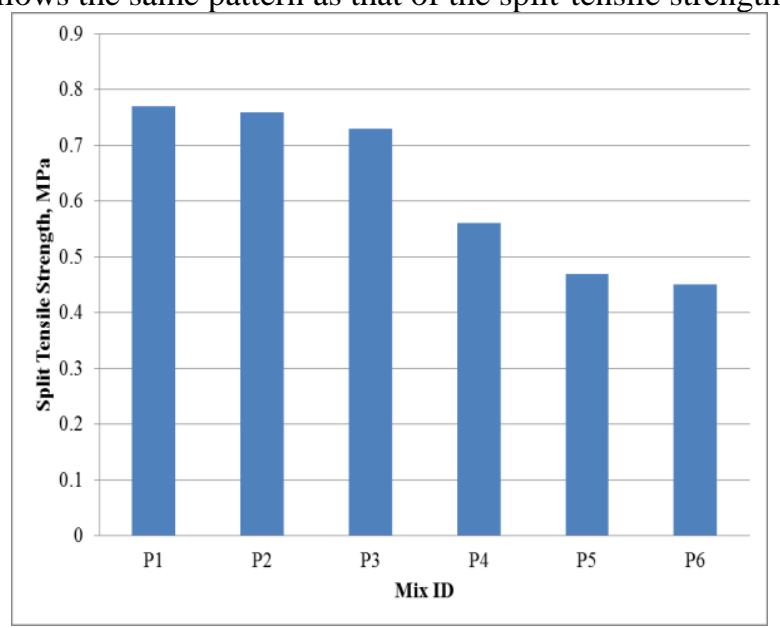

Fig. 3. Split Tensile Strength of Pervious Concrete

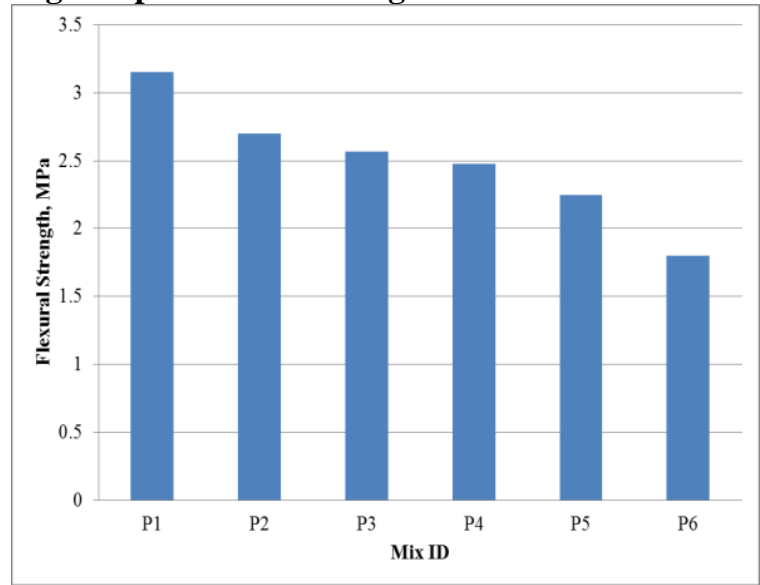

Fig. 4. Flexural Strength of Pervious Concrete 
From the investigations on the pervious concrete, it was found that the all the strength results followed the same pattern with respect to the variation of void content. The strength properties decreased with respect to the increase in the void content and vice versa. From the strength results, it was observed that mechanical properties mainly depend on the void content of the concrete. Based on the results, it was observed that if strength is required there is a need to compromise on the permeability properties and where high permeability is required, there is a need to compromise on the strength results. From the experimental work performed on pervious concrete, mix proportion with $15 \%$ void content can be used for low volume traffic pavements which had achieved a compressive strength of $15 \mathrm{MPa}$.

\section{CONCLUSIONS}

Based on the results on pervious concrete, following salient conclusions can be arrived at

$>$ Mix proportion with $15 \%$ void content resulted in higher strength than the other mixtures. Similar results have been observed in both split-tensile and flexural strength. The mix P1 has achieved a maximum compressive strength of $15 \mathrm{~N} / \mathrm{mm}^{2}$. Also the flexural strength of mix P1 was around $3 \mathrm{~N} / \mathrm{mm}^{2}$. Therefore P1 Mix may be used for concreting low traffic pavements.

$>$ The density of the pervious concrete varies from 1,900 to $2,200 \mathrm{~kg} / \mathrm{m}^{3}$. This revealed that the density depends on the amount of voids present in the pervious concrete.

\section{REFERENCES}

1. Report on Pervious Concrete (ACI 522R-10). 2. ACI Committee 522, ACI 522R-10; 2010. p. 42.

2. Tennis PD, Leming ML, Akers DJ. Pervious concrete pavements. Skokie (IL): Portland Cement Association; 2004.

3. Kevern JT, Schaefer VR, Wang K, Suleiman MT. Pervious concrete mixture proportions for improved freeze-thaw durability. J ASTM International 2008; 5(2):12.

4. Schaefer V R, Wang K, Suleiman M, and Kevern J T. Mix Design Development for Pervious Concrete in Cold Weather Climates. Report 2006-01. Iowa Department of Transportation, Ames.

5. National Ready Mixed Concrete Association (2004). Freeze-Thaw Resistance of Pervious Concrete. NRMCA, Silver Spring, MD.

6. Huang B, Wu H., Shu X. and Burdette E.G., Laboratory evaluation of permeability and strength of polymer-modified pervious concrete, Construction and Building Materials, 24 (2010), pp 818-823.

7. Yang J, and Guoliang J. Experimental Study on Properties of Pervious Concrete Pavement Materials. Cement and Concrete Research, (2003), pp. 381-386.

8. Master Builders Degussa Admixtures Inc (2005), Product Information: Pervious Concrete, Master Builders.

9. ACI Committee 330 (2001) Guide for Design and Construction of Concrete Parking Lots, ACI 330.1R-01, American Concrete Institute.

10. Putman BJ, Neptune AJ, Comparison of test specimen preparation, techniques for pervious concrete pavements, Construction and Building Materials, 25(2011),3480-3485

11. Deo O, Neithalath, N, Compressive response of pervious concrete proportioned for desired properties, Construction and Building Materials, 25(2011), 4181-4189

12. IS 12269 Specifications for 53 grade OPC. Bureau of Indian Standards, New Delhi, 1987.

13. IS 2386 Methods of test for aggregate concrete. Bureau of Indian Standards, New Delhi, 1968.

14. IS 456 Plain and reinforced concrete: Code of practice. Bureau of Indian Standards, New Delhi, 2000.

15. IS 516 Method of test for strength of concrete. Bureau of Indian Standards, New Delhi, 1959.
16. Malayali, A.B. and Chokkalingam, R.B., Mechanical properties of geopolymer pervious concrete, International Journal of Civil Engineering and Technology, 9(11), 2018, pp 2394-2400s

\section{AUTHORS PROFILE}

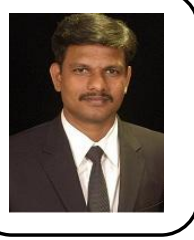

Ramesh Babu Chokkalingam, completed his Ph.D. from IIT Chennai. He has more than 10 years of experience in teaching and research. His areas of research includes pervious concrete, geopolymer concrete, and high volume flyash concrete. 